\title{
The differences in Quality of Life between the Heroin Addicts treated in Methadone Program and Addicts treated in the Frame of Therapeutic Community Program
}

\author{
Danijel Bevanda ${ }^{1}$, Ivan Tomić ${ }^{1}$, Milenko Bevanda ${ }^{1}$, Siniša \\ Skočibušić ${ }^{2}$ Nikolina Palameta ${ }^{3}$, Marko Martinac ${ }^{3}$ \\ ${ }^{1}$ University Hospital Mostar, Internal Medicine Clinic, Mostar, Bosnia and Herzegovina, \\ ${ }^{2}$ Center for Prevention and Out-hospital Treatment of Addictions, Mostar, Bosnia and \\ Herzegovina, ${ }^{3}$ Center for Mental Health, Mostar, Bosnia and Herzegovina
}

\begin{abstract}
Aim of the study was comparing the quality of life of addicts treated in frame of methadone substitution programs and addicts undergoing the rehabilitation on the frame of therapeutic community. We have done a crossover study in the Center for Prevention and Out-patient Treatment in Mostar. We have included 60 subjects in our study. All of them were heroin addicts, referred to the Center for Prevention and Out-patient Treatment in Mostar, who satisfied the DSM-IV criteria for the addiction disease. The subjects have been divided in three groups: 1$)$ group of just-admitted patients $(N=20), 2)$ group of patients who had spent six months in methadone program $(\mathrm{N}=20)$ and 3$)$ group of patient who had spent six months in the therapeutic community program $(\mathrm{N}=20)$. In this study, we have gathered data for social-demographic variables such as age, education, marital and professional status and variables related to the addiction, such as duration of addiction, manner of drug administration, alcohol use and presence of HCV, HBV or HIV viral infections. For the estimation of quality of life, we have used the "Quality of life index", to measure the perception of the important areas of life, such as health and functioning in the fields of social, economic, psychological and spiritual domains. A majority of subjects from this sample had achieved the secondary school education and were of similar age, unmarried, mostly unemployed and only a smaller number of them were living alone, out of their primary families. The groups tested have not significantly differed considering those living conditions which reflect the quality of life. The results of addiction variables had showed that a majority of subjects administered the drug intravenously, there were no significant differences concerning the
\end{abstract}

Copyright @ 2017 KBCSM, Zagreb

e-mail: alcoholism.kbcsm@gmail.com•www.http//hrcak.srce.hr/acoholism

Correnspodence to: Marko Martinac Centar za mentalno zdravlje Mostar Hrvatskih branitelja bb 88000 Mostar, Bosna i Hercegovina e-mail: marko.martinac@tel.net.ba 
duration of addiction and the most of the subjects had drunk no alcohol. We have not detected any cases of HIV infection, while a significant number of subjects had been infected with hepatitis B virus. This study revealed significant differences in quality of life between the groups tested. The groups of subjects who had undergone the methadone program and the group of those treated in the frame of therapeutic community showed significantly higher scores on quality of life scales compared to the group of just-admitted patients, while there were no such differences between the group of subjects who had undergone the methadone program and the group of those treated in the frame of therapeutic community. The data obtained indicate that the methadone treatment is similarly effective concerning the quality of subjects' life as the treatment in the frame of therapeutic community.

Key words: opiate dependence, methadon, buprenorphin, quolity of life

\section{Introduction}

The addiction to heroin is a severe disorder and its treatment represents a complicated, long-lasting process, which includes a series of various interventions which have to be constantly adjusted to patients' present state and his abilities to accept the therapy. The addiction is very resistant to treatment and if the program is not at the same time, enough influential and persistent, but also acceptable to the addict to stick to it for months or even years, the expected results will not be achieved. Retention to the program, abstinence from the illicit drugs, reduction of illegal activities and improving the aspects of socially acceptable behaviour are the best indicators of therapeutic efforts [1-5].

Already thirty years ago, the most of western-European countries and USA, Canada and Australia have accepted the use of methadone as a recognized method for treatment of opiate addicts and a useful tool in the frame of 'harm-reduction' approach for helping the not-motivated or incurable heroin addicts. Methadone enables those patients to stop or significantly reduce taking heroin. Although methadone does not create the feeling of euphoria similar to the effect of heroin, it replaces the biological lack of endorphins at the opioid receptors in brain and, with its help, the patient can achieve a psychophysical balance and control the pathological addict's craving. The use of methadone is the best way to attract the addicts from the street to the process of treatment and, if it is well organized and spread, can ultimately direct many addicts towards the programs that would help them in stabilizing the permanent abstinence [1-5].

In the evaluation study carried out by the American National Institute for Drugs (NIDA) it has been found that the substitution therapy reduces users' heroin intake for $70 \%$, and their criminal activity by $57 \%$. [6]. It has also been reported that the countries which use methadone attract up to $75 \%$ of opiate addicts to their programs, while those that do not use it, achieve less than $20 \%$, making the mortality of addicts due to overdose very high. A large number of addicts included in substitution programs function better socially, i.e. better fulfill their duties at the workplace and in families and display significantly less dealings with criminal activities, particularly with selling drugs, thus reducing the risk of initial drug abuse among the healthy population. Application of methadone improves the physical and mental health 
of the addict, his life gets longer and the risk for early sudden death is reduced. By using methadone, physical and mental health of addicts is improved, their lifespan prolonged i.e. the risk of sudden death is reduced. The addicts in substitution programs are less dangerous concerning the spread of HIV infection, hepatitis and encouraging others to take drugs. The use of methadone in pregnancy is absolutely indicated: it reduces the risk of unwanted pregnancy termination and the risk of damaging the fetus. [1].

"Drug free" residential treatment of addictions in the frame of therapeutic communities (TZ) started in early sixties as groups of self and mutual help, as an alternative to the existing conventional programs. The mean duration of stay differs from $T Z$ to $T Z$ (18-60 months). The staff consists mostly of former addicts, while the rest of the staff consists of medical professionals from the field of mental health, psychologists, defectologists, and pedagogues and similar. The aim of staying in TZ is a global change of lifestyle, including abstinence from the illegal substances, elimination of anti-social activities, gathering skills for job-finding and the development of pro-social efforts and values. In TZ, detoxification is the condition to enter the treatment and not the goal of it. Most of the patients who enter TZ already have histories of multiple drug abuse, significantly disturbed psychosocial functioning and consequently, significantly lower quality of life. The patients are mostly male, older than 25 years of age, coming from broken families, without any significant periods of active working and with accentuated problems with the law. They frequently have more pronounced depression, anxiety, personality disorders, difficulties in thought process, affective disorders, i.e. whatever the anamnesis, the level of psychological damage is high.

Abandoning the program happens most frequently during the first month of treatment and averages about $30-40 \%$, and then drops during the later stages of program. Finishing the program in long-lasting stationary programs averages about $10-25 \%$, while the annual retention level equals from 20 to $30 \%$. The main predictors of program abandonment are severe criminal history and pronounced psychopathology. TZ program is efficient for those who stay in it long enough to benefit from the results of treatment $[1,2]$.

Quality of life has drawn much interest of medical investigators in the last decade [7]. Compared to the earlier traditional clinical studies, measuring the quality of life is more convenient for the evaluation of social and emotional dimension of disease course and treatment success and provide the general insight of the influence that the disease and the treatment have on patients functioning in several important areas of life [8].

The concept of quality of life has also been accepted an an important method of evaluating the programs of treatment of the addictions to psychoactive substances [9]. Programs of maintenance with methadone are probably the most investigated in the field of treatment of addiction to opiates and the dominant conclusion is that methadone is an efficient treatment tool and thus, lately, easy as possible access to these programs 'to all who need them' is promoted. [10]. The efficiency of methadone therapy is mostly supported by the indicators which appear on the broader social level (social functioning, criminality level decrease, reduction of psychoactive substances abuse) while a smaller number of studies analyzed the perception of health and well-being from the perspective of the 
patients themselves, while the therapy with methadone is mostly considered a "biomedical treatment for social rehabilitation " [11].

So far, it has been several efforts to evaluate the influence of opiate addiction and its treatment to the quality of patients' life. A smaller number of previous studies dealt with various maintenance treatments, while the treatment in frame of therapeutic community has not yet been the object of such studies [12,13].

That is why the aim of this study had been to compare the quality of addicts' life among those treated in methadone maintenance programs and those treated in the therapeutic communities.

\section{Materials and methods}

A cross-study has been carried out in the Center for Prevention and Out-patient Treatment of Addictions in Mostar. The study included 60 subjects, all of them males, mean age $31,87 \pm 7(\mathrm{M} \pm \mathrm{SD})$ years, mean addiction duration $6,78 \pm 5,02(\mathrm{M} \pm \mathrm{SD})$ years. All of the subjects were heroin addicts referring to the Center for Prevention and Out-patient Treatment of Addictions in Mostar, who had satisfied the DSM-IV criteria for establishing the diagnosis of addiction.

Subjects have been divided in three groups:

1. group of just-admitted patients $(\mathrm{N}=20)$

2. group of patients who had spent six months in a methadone program $(\mathrm{N}=20)$

3. group of patients who had spent six months in a therapeutic community program $(\mathrm{N}=20)$.

In this study, we have gathered data for social-demographic variables such as age, education, marital and professional status and variables related to the addiction status, such as duration of addiction, manner of drug administration, alcohol use and presence of $\mathrm{HCV}, \mathrm{HBV}$ or HIV viral infections. For the estimation of quality of life, we have used the "Quality of life index", to measure the subjects' perception of the important areas of life, such as health and functioning in the fields of social, economic, psychological, spiritual and family domains.

The study had been approved by the Ethical committee and carried out according to the Rules of Good Clinical Practice and Helsinki Declaration.

\section{Statistical analysis of data}

The study results have been stored in MS Excel 2007 database and SPSS 17 statistical program has been used for all statistical calculations. In the analysis of data, we have used the methods of descriptive statistics. Non-parametric variables have been shown as frequencies and percentages. Parametric variables have been shown as an arithmetical means and standard deviations. The data distribution has been analyzed by means of using the Kolmogoroff-Smirnoff Test. The observed differences have been tested for significance using the Chi-square Test and Fisher's Exact Test for categorical variables. Testing the differences between the parametric variables has been done using the Oneway Analysis of Variance and the differences between the individual groups by means of Sheffe Test. The level of statistical significance has been set to $\mathrm{p}<0,05$.

\section{Results}

Social-demographic and clinical characteristics of the sample

The majority of patients from our sample had finished the secondary school educa- 
tion, a smaller number finished universities, while there were no subjects with just the primary school education $\left(\chi^{2}=45,067\right.$; $\mathrm{df}=1$; $\mathrm{p}<0,001)$ The most of the subjects have not been married, while a smaller proportion had been married or divorced $\left(\chi^{2}=43,600 ; \mathrm{df}=2\right.$; $\mathrm{p}<0,001)$. The data concerning the professional status had indicated that a significantly greater number of subjects had been unemployed $\left(\chi^{2}=38,400 ; d f=1 ; p<0,001\right)$. Significantly more of the subjects lived with their parents, while a smaller percentage had lived alone $\left(\chi^{2}=38,400 ; \mathrm{df}=1 ; \mathrm{p}<0,001\right)$. The greatest percentage of our subjects had been taking drugs intravenously, a smaller percentage sniffed, while the smallest percentage of them had been taking heroin by means of smoking $\left(\chi^{2}=33,400 ; \mathrm{df}=2 ; \mathrm{p}<0,001\right)$.

We have also gathered the data concerning the prevalence of sexually transmitted diseases and diseases transmitted by blood, such as HIV, HCV and HBV. We have not found any subjects infected with HIV in our sample, while more than $50 \%$ of the subjects from the sample had been infected with hepatitis $C$ virus $\left(\chi^{2}=1,143 ; d f=1 ; p=0,285\right)$. The majority of subjects had been consuming no alcohol at all or drinking sporadically, while a smaller number of subjects had been drinking alcohol regularly every day or abstaining $\left(\chi^{2}=27,200 ; \mathrm{df}=5 ; \mathrm{p}<0,001\right)$.

Using the Chi-square test, we have found a significant difference in the level of education between the groups tested; more subjects at the admission had finished the university education, while in the other two groups, those with secondary school education prevailed. There were not any significant differences between the groups neither concerning the marital and professional status, nor in the living conditions (Table 1).

Table 1. Social-demographic characteristics

\begin{tabular}{|c|c|c|c|c|c|c|c|c|}
\hline & \multicolumn{6}{|c|}{ Group } & \multirow{3}{*}{$\chi^{2}$} & \multirow{3}{*}{$\mathrm{p}$} \\
\hline & \multicolumn{2}{|c|}{ Admission } & \multicolumn{2}{|c|}{ Methadone } & \multicolumn{2}{|c|}{ Community } & & \\
\hline & $\mathrm{N}$ & $\%$ & $\mathrm{~N}$ & $\%$ & $\mathrm{~N}$ & $\%$ & & \\
\hline Education & & & & & & & 6,209 & $0,030^{*}$ \\
\hline SSS & 16 & 80,0 & 20 & 100,0 & 20 & 100,0 & & \\
\hline VSS & 4 & 20,0 & 0 & 0,0 & 0 & 0,0 & & \\
\hline Marriage & & & & & & & 5,901 & $0,184^{*}$ \\
\hline Not-married & 14 & 70,0 & 12 & 60,0 & 18 & 90,0 & & \\
\hline Married & 4 & 20,0 & 4 & 20,0 & 2 & 10,0 & & \\
\hline Divorced & 2 & 10,0 & 4 & 20,0 & 0 & 0,0 & & \\
\hline Work & & & & & & & 0,223 & $1 *$ \\
\hline Unemployed & 18 & 90,0 & 18 & 90,0 & 18 & 90,0 & & \\
\hline Employed & 2 & 10,0 & 2 & 10,0 & 2 & 10,0 & & \\
\hline Living with & & & & & & & 0,223 & $1 *$ \\
\hline Alone & 2 & 10,0 & 2 & 10,0 & 2 & 10,0 & & \\
\hline Family & 18 & 90,0 & 18 & 90,0 & 18 & 90,0 & & \\
\hline
\end{tabular}

*Fisher's Exact Test 
Table 2. Habits of alcohol drinking in the groups tested

\begin{tabular}{|c|c|c|c|c|c|c|c|c|}
\hline & \multicolumn{6}{|c|}{ Group } & \multirow{3}{*}{$\chi^{2}$} & \multirow{3}{*}{$\mathrm{p}$} \\
\hline & \multicolumn{2}{|c|}{ Admission } & \multicolumn{2}{|c|}{ Methadone } & \multicolumn{2}{|c|}{ Community } & & \\
\hline & $\mathrm{N}$ & $\%$ & $\mathrm{~N}$ & $\%$ & $\mathrm{~N}$ & $\%$ & & \\
\hline Alcohol & & & & & & & 18,679 & $0,017 *$ \\
\hline Does not drink & 8 & 40,0 & 4 & 20,0 & 10 & 50,0 & & \\
\hline Occasionally & 6 & 30,0 & 8 & 40,0 & 2 & 10,0 & & \\
\hline Weekends & 2 & 10,0 & 2 & 10,0 & 4 & 20,0 & & \\
\hline Frequently & 0 & 0,0 & 4 & 20,0 & 2 & 10,0 & & \\
\hline Every day & 4 & 20,0 & 0 & 0,0 & 0 & 0,0 & & \\
\hline Abstinent & 0 & 0,0 & 2 & 10,0 & 2 & 10,0 & & \\
\hline
\end{tabular}

*Fisher's Exact Test

As shown in Table 2, the alcohol had been subjects from methadone group, mostly spoconsumed in greater percentage among the radically, in special occasions

Table 3. The differences in variables related to the addiction between the groups tested

\begin{tabular}{|c|c|c|c|c|c|c|c|c|}
\hline & \multicolumn{6}{|c|}{ Group } & \multirow{3}{*}{$\chi^{2}$} & \multirow{3}{*}{$\mathrm{p}$} \\
\hline & \multicolumn{2}{|c|}{ Admission } & \multicolumn{2}{|c|}{ Methadone } & \multicolumn{2}{|c|}{ Community } & & \\
\hline & $\mathrm{N}$ & $\%$ & $\mathrm{~N}$ & $\%$ & $\mathrm{~N}$ & $\%$ & & \\
\hline Way of administration & & & & & & & 16,915 & 0,001 \\
\hline $\mathrm{Iv}$ & 10 & 50,0 & 10 & 50,0 & 20 & 100,0 & & \\
\hline Sniffing & 8 & 40,0 & 8 & 40,0 & 0 & 0,0 & & \\
\hline Smoking & 2 & 10,0 & 2 & 10,0 & 0 & 0,0 & & \\
\hline $\mathrm{HCV}$ & & & & & & & 23,333 & $<0,001$ \\
\hline No & 12 & 66,7 & 12 & 66,7 & 0 & 0,0 & & \\
\hline Yes & 6 & 33,3 & 6 & 33,3 & 20 & 100,0 & & \\
\hline $\mathrm{HBV}$ & & & & & & & 2,495 & $0,322 *$ \\
\hline No & 18 & 100,0 & 18 & 100,0 & 18 & 90,0 & & \\
\hline Yes & 0 & 0,0 & 0 & 0,0 & 2 & 10,0 & & \\
\hline
\end{tabular}

*Fisher's Exact Test 
Table 4. The differences in quality of life between the groups tested

\begin{tabular}{|c|c|c|c|c|c|c|c|c|}
\hline \multirow{3}{*}{ QOLY Index } & \multicolumn{6}{|c|}{ Groups } & \multirow{3}{*}{$\mathrm{F}$} & \multirow{3}{*}{$\mathrm{p}$} \\
\hline & \multicolumn{2}{|c|}{ Admission } & \multicolumn{2}{|c|}{ Methadone } & \multicolumn{2}{|c|}{ Community } & & \\
\hline & $\overline{\mathrm{X}}$ & SD & $\overline{\mathrm{X}}$ & $\mathrm{SD}$ & $\overline{\mathrm{X}}$ & $\mathrm{SD}$ & & \\
\hline Scale of satisfaction & 106,50 & 21,867 & 136,10 & 28,853 & 134,60 & 21,780 & 9,344 & $<0,001$ \\
\hline Scale of importance & 150,10 & 22,861 & 173,40 & 5,734 & 166,40 & 16,301 & 10,443 & $<0,001$ \\
\hline
\end{tabular}

As visible from Table 3, the greatest percentage of patients who had administered heroin to organism intravenously belonged to the group of subjects from therapeutic communities and this group had also showed the greatest level of $\mathrm{HCV}$ infection, while no significant differences had been observed concerning the HBV infection.

Using the One-way analysis of variance, we have found significant differences in quality of life between the groups tested (Table 4).

Table 5. Multiple comparisons; Scheffe Test

\begin{tabular}{|c|c|c|c|}
\hline QOLY Index & & & $\mathrm{p}$ \\
\hline \multirow{6}{*}{ Scale of satisfaction } & \multirow{2}{*}{ admission } & methadone & 0,001 \\
\hline & & community & 0,003 \\
\hline & \multirow{2}{*}{ methadone } & admission & 0,001 \\
\hline & & community & 0,981 \\
\hline & \multirow{2}{*}{ community } & admission & 0,003 \\
\hline & & methadone & 0,981 \\
\hline \multirow{6}{*}{ Scale of importance } & \multirow{2}{*}{ admission } & methadone & $<0,001$ \\
\hline & & community & 0,011 \\
\hline & \multirow{2}{*}{ methadone } & admission & $<0,001$ \\
\hline & & community & 0,414 \\
\hline & \multirow{2}{*}{ community } & admission & 0,011 \\
\hline & & methadone & 0,414 \\
\hline
\end{tabular}


For multiple comparisons between the groups, we have used Sheffe Post-hoc Test (Table 5). The groups of subjects treated in methadone program and subjects in the program of therapeutic community showed significantly higher scores on scales of satisfaction with important areas of life $(p=0,001$; $p=0,003$; Schefe post hoc test) and on scales of importance od particular areas of life $(p<0,001 ; p=0,011 ;$ Schefe post hoc test) compared to the group of patients just admitted to treatment. There were no significant differences in scales previously mentioned between the groups of patients from methadone programs and those from therapeutic communities $(p=0,981 ; p=0,414$; Schefe post hoc test).

\section{Discussion}

According to the results of this study, the most of the patients from our sample had a secondary school education and were of similar age, unmarried, mostly unemployed and only a smaller number of them were living alone, out of their primary families. The groups tested had not significantly differed according to living conditions which reflect the quality of life. The results of analysis of the addiction variables had shown that a majority of subjects administered the drug intravenously, that there were no significant differences concerning the duration of addiction and that the most of the subjects had drunk no alcohol. We have not detected any cases of HIV infection, while a significant number of subjects had been infected with hepatitis B virus. This study revealed significant differences in quality of life between the groups tested. The groups of subjects who had undergone the methadone program and the group of those treated in the frame of therapeutic community showed significantly higher scores on quality of life scales compared to the group of just-admitted patients, while there were no such differences between the group of subjects who had undergone the methadone program and the group of those treated in the frame of therapeutic community.

The study carried out by Giacomuzzi et al. included 67 subjects addicted to opiates, 38 of which had been treated with methadone and 29 with buprenorphine. The subjects have been similar according to all their basic characteristics. Neither subjects from buprenorphine program, nor those from methadone program had shown any significant differences in any areas of quality of life after 24 weeks spent in the program of treatment. The results of this study suggest that the treatment with buprenorphine or methadone is equally effective considering the effect to quality of life, which is in concordance with this study [13].

In a similar study, dealing with patients in methadone maintenance program of treatment, Torrens et al. have analyzed the changes of quality of life related to the health status of subjects followed throughout a three-year period. The results of this study have shown that the patients on methadone therapy showed a significant improvement of measured quality of life parameters already early in the course of study, inside the period of 12 months, which is also in accordance with the results of our study [9].

There were also several other studies that had reported that heroin addicts at the admission to methadone programs already have a high level of physical and mental health damage, but also that the quality of life significantly improves in the course of remaining in programs of methadone maintenance. This improvement is the most visible at the 
end of the first month of treatment, and detectable even before the other indexes are modified (like heroin abuse and criminal activities) [14].

\section{Conclusion}

The data obtained suggest that the treatment with methadone is equally effective as

\section{References}

1. Sakoman S. Društvo bez droge? Hrvatska nacionalna strategija. Zagreb: Institut društvenih znanosti Ivo Pilar, 2001.

2. Galanter M, Kleber HH. Textbook of Substance Abuse Treatment, 2nd ed. New York: The American Psychiatric Press, 1999.

3. The White House. National Drug Control Strategy: Reclaiming Our Communities from Drugs and Violence. Washington D.C.: Office of National Drug Control Policy. 1994.

4. Leshner AI. When the question is drug abuse and addiction, the answer is "All of the above". NIDA Notes; 2001:16, 3-5.

5. The White House. National Drug Control Strategy: Strategic Goals and Objectives. Washington D.C.: Office of National Drug Control Policy. 2000.

6. European Monitorning Centre for Drugs and Drug Addiction.. Annual Report on the State of the Drugs Problem in the European Union. Lisboa: EMCDDA. 2000.

7. Leisse M, Kallert TW. Social integration and the quality of life of schizophrenic patients in different types of complementary care. Eur Psychiatry. 2000;15:450-60.

8. Donald M, Dower J, Lucke J, Raphael B. Prevalence of adverse life events, depression and sui- a stay in therapeutic community concerning the quality of life of the patients.

\section{Acknowledgements}

None

\section{Conflict of interest}

None to declare cidal thoughts and behaviour among a community sample of young people aged 15-24 years. Aust N Z J Public Health. 2001;25:426-32.

9. Torrens M, San L, Martinez A, Castillo C, Domingo-Salvany A, Alonso J. Use of the Nottingham Health Profile for measuring health status of patients in methadone maintenance treatment. Addiction. 1997;92:707-16.

10. Farrell M, Ward J, Mattick R, Hall W, Stimson GV, des Jarlais D i sur. Methadone maintenance treatment in opiate dependence: a review. BMJ. 1994;309:997-1001.

11. Fischer B, Rehm J, Kim G, Kirst M. Eyes wide shut?--A conceptual and empirical critique of methadone maintenance treatment. Eur Addict Res. 2005;11:1-9.

12. Fischer B. Prescriptions, power and politics: the turbulent history of methadone maintenance in Canada. J Public Health Policy. 2000;21:187-210.

13. Giacomuzzi SM, Riemer Y, Ertl M, Kemmler G, Rössler H, Hinterhuber $\mathrm{H}$ i sur. Buprenorphine versus methadone maintenance treatment in an ambulant setting: a health-related quality of life assessment. Addiction. 2003;98:693-702.

14. Ryan CF, White J. Health status at entry to methadone maintenance treatment using the SF-36 health survey questionnaire. Addiction. 1996;91:3 9-4 5 . 


\section{Razlike u kvaliteti života ovisnika o heroinu liječenih u metadonskom programu i ovisnika liječenih u programu terapijske zajednice}

Sažetak - Cilj istraživanja bio je usporediti kvalitetu života ovisnika liječenih u supstitucijskom metadonskom programu i ovisnika na rehabilitaciji u terapijskoj zajednici. Provedeno je presječno istraživanje u Centru za prevenciju i izvanbolničko liječenje ovisnosti u Mostaru. U istraživanje je uključeno 60 ispitanika. Svi su ovisnici o heroinu koji su se javili u Centar za prevenciju i izvanbolničko liječenje ovisnosti u Mostaru, a koji zadovoljavaju DSM-IV kriterije za dijagnozu ovisnosti. Ispitanici su podijeljeni u tri skupine: 1) skupinu tek primljenih pacijenata ( $\mathrm{N}=20)$, 2) skupinu pacijenata koji su proveli 6 mjeseci u metadonskom programu $(\mathrm{N}=20)$ i3) skupinu pacijenta koji su proveli 6 mjeseci u programu terapijske zajednice $(\mathrm{N}=20)$. U istraživanju su prikupljane socidemografske varijable kao što su dob, edukacija, bračni i radni status, te varijable vezane za ovisnost kao što su dužina ovisničkog staža, način uzimanja droge, uporaba alkohola te prisutnosti infekcije virusima HCV, HBV i HIV. Za procjenu kvalitete života koristio "Quality of life index" kojim se mjerila percepcija važnih životnih područja kao što su zdravlje i funkcioniranje, socijalno i ekonomsko, psihološko i spiritualno, te obiteljsko područje. Većina ispitanika u uzorku je bila srednjoškolski obrazovana, podjednake dobi, neoženjeni, najveći dio je bio bez posla, a samo mali broj je živio sam van primarne obitelji. Ispitivane skupine se nisu značajno razlikovale prema uvjetima življenja koji su pokazatelji kvalitete života. Rezultati istraživanja ovisničkih varijabli pokazuju da je većina ispitanika drogu uzimala intravenskim putem, nije bilo razlika u trajanju ovisničkog staža među skupinama, te ih većina nije pila alkohol. Nije nađen nijedan slučaj infekcije HIV-om, a veći broj ispitanika u uzorku su bili zaraženi virusom hepatitisa C, dok je vrlo mali broj ispitanika bio zaražen virusom hepatitisa B. U ovom istraživanju su nađene značajne razlike u kvaliteti života među ispitivanim skupinama. Skupine ispitanika liječenih u metadonskom programu i u programu terapijske zajednice pokazale su značajno veće rezultate na skalama kvalitete života u odnosu na skupinu tek primljenih pacijenata, a između skupine ispitanika koji su bili u metadonskom programu liječenja i skupine u terapijskoj zajednici nije bilo takvih razlika. Dobiveni podaci ukazuju na činjenicu da je liječenje metadonom podjednako djelotvorno kao i boravak u terapijskoj zajednici po utjecaju na promjene u kvaliteti života ispitanika.

Ključne riječi: ovisnost o opijatima, metadon, buprenorfin, kvaliteta života 